\title{
The Effect of BCG vaccine on COVID-19 severity and mortality
}

\section{BCG aşısının COVID-19 ağırlığına ve mortalitesine etkisi}

\author{
Tayfun Çalışkan ${ }^{1}$, Bengü Saylan ${ }^{1}$
}

\begin{abstract}
Aim: To investigate the effect of Bacille Calmette-Guérin (BCG) vaccine on the severity and mortality of the disease in hospitalized patients with COVID-19 in this study.

Methods: This study was conducted as a retrospective observational study in a tertiary reference hospital in Turkey. The patients were divided into two groups as BCG scar positive and negative according to the presence of BCG scar. BCG scar positive and negative groups were compared in terms of radiological involvement, oxygen desaturation, need for intensive care unit (ICU) and intubation, and mortality.

Results: BCG scar negative patients required more inpatient treatment $(\mathrm{p}=0.001)$. The radiological involvement was more severe in BCG scar negative group $(\mathrm{p}=0.016)$. Forty-one $(22.7 \%)$ patients in the BCG scar positive group and twenty-two $(42.3 \%)$ patients in the BCG scar negative group were treated in the ICU, and the difference was statistically significant $(\mathrm{p}=0.007)$. More patients in the BCG scar negative group had oxygen desaturation than the BCG scar positive group $(59.6 \%$ vs. $40.9 \%, \mathrm{p}=0.018)$. The $\mathrm{BCG}$ scar negative group needed more intubation $(21.2 \%$ and $8.8 \%, \mathrm{p}=0.024)$. Nine $(17.3 \%)$ patients in the BCG scar negative group and $12(6.6 \%)$ patients in the BCG scar positive group died, and the difference was statistically significant $(\mathrm{p}=$ $0.027)$.

Conclusion: The length of hospital stay was longer, radiological involvement was more severe, the need for ICU and intubation, oxygen desaturation and mortality were higher in BCG-unvaccinated patients with COVID-19.
\end{abstract}

Keywords: BCG vaccine, COVID-19, SARS-CoV-2, pandemics, prognosis

Öz

Amaç: Hastanede yatan COVID-19 hastalarında Bacille Calmette-Guérin (BCG) aşıSı yapılmış olmanın hastalığın ciddiyeti ve mortalitesi üzerine etkisini araştırmaktır.

Yöntemler: Bu çalışma, Türkiye'deki üçüncü basamak bir referans hastanesinde geriye dönük gözlemsel bir çalışma olarak gerçekleştirildi. Hastalar BCG skarının varlı̆̆ına göre BCG skarı pozitif ve negatif olarak iki gruba ayrıldı. BCG skarı pozitif ve negatif gruplar radyolojik tutulum, oksijen desatürasyonu, yoğun bakım ünitesi (YBÜ) ihtiyacı ve entübasyon ve mortalite açısından karşılaştırıldı.

Bulgular: BCG skarı negatif hastaların daha uzun süre yatarak tedavi ihtiyacı oldu $(\mathrm{p}=0,001)$. Radyolojik tutulum, BCG skarı negatif grupta daha ağırdı $(p=0,016)$. BCG skarı pozitif grupta $41(\% 22,7)$ hasta ve BCG skarı negatif grupta $22(\% 42,3)$ hasta YBÜ'de tedavi edildi ve aradaki fark istatistiksel olarak anlamlıydı $(\mathrm{p}=$ $0,007)$. BCG skarı negatif grupta BCG skarı pozitif gruba göre daha fazla hastada oksijen desatürasyonu vardı ( $\% 59,6$ ve $\% 40,9, p=0,018$ ). BCG skarı negatif grup daha fazla entübasyona ihtiyaç duydu $(\% 21,2$ ve $\% 8,8$, $\mathrm{p}=0,024)$. BCG skarı negatif grupta $9(\% 17,3)$ hasta ve BCG skarı pozitif grupta $12(\% 6,6)$ hasta öldü ve aradaki fark istatistiksel olarak anlamlıydı $(\mathrm{p}=0,027)$.

Sonuç: BCG ile aşılanmamış COVID-19 hastalarında hastanede kalış süresi daha uzun, radyolojik tutulum daha şiddetli, yoğun bakım ve entübasyon ihtiyacı, oksijen desatürasyonu ve mortalite daha yüksekti.

Anahtar Kelimeler: BCG aşısı, COVID-19, SARS-CoV-2, pandemi, prognoz
1 Health Sciences University, Sultan 2.Abdulhamit Han Training and Research Hospital, Department of Pulmonology, Istanbul, Turkey.

\section{TC: $0000-0002-7905-2430$ \\ BS: 0000-0002-5922-0847}

Ethics Committee Approval: This study was approved by the Ethics Committee of the Umraniye Training and Research Hospital (No: 285, Date: $26^{\text {th }}$ June, 2020).

Etik Kurul Onayı: Bu çalışma Ümraniye Eğitim ve Araştırma Hastanesi Etik Kurulu'ndan karar no:285 ve 26.06.2020 tarihinde etik kurul izni alınmıştır.

Conflict of Interest: No conflict of interest was declared by the authors.

Çıkar Çatışması: Yazar çıkar çatışması bildirmemiştir.

Financial Disclosure: The authors declared that this case has received no financial support.

Finansal Destek: Yazarlar bu çalışma için finansal destek almadıklarını beyan etmişlerdir.

Geliş Tarihi / Received: 27.11.2020

Kabul Tarihi / Accepted: 08.03.2021

Yayın Tarihi / Published: 01.04.2021

Sorumlu yazar / Corresponding author:

Tayfun Caliskan

Adres/Address: Department of Pulmonology, Health Sciences University, Sultan 2.Abdulhamid Han Training and Research Hospital, Tibbiye Avenue, Selimiye Street, 34688, Uskudar, Istanbul, Turkey.

e-mail: drtcaliskan@yahoo.com

Tel/Phone: +902165422020

Copyright (C) ACEM 


\section{Introduction}

Bacille Calmette-Guérin (BCG) vaccine is a live attenuated vaccine that has been used widely to prevent tuberculosis disease for about 100 years. BCG's protection against pulmonary tuberculosis varies between 0 and $80 \%$, and it primarily protects against severe forms of tuberculosis such as disseminated and meningitis tuberculosis in children [1]. World Health Organization (WHO) recommends BCG vaccination for countries with a high incidence of tuberculosis and therefore it is not included in the routine vaccination program in countries with low tuberculosis incidence [2]. Turkey has a universal BCG vaccination policy.

The coronavirus disease 2019 (COVID-19) pandemic still continues. Although there are a few vaccines that have been developed against COVID-19, these vaccines have not been approved yet. After the approval process of the vaccines, it is estimated that the production and distribution of the vaccines worldwide and the vaccination process can be completed in about approximately two years. BCG vaccine is protective against tuberculosis and the vaccine is also protective against different respiratory diseases, especially those of viral origin [3]. BCG induces trained immunity and has been proposed to be protective against COVID-19 [4]. There are studies reporting that the severity and mortality of COVID-19 disease was lower in countries with national BCG vaccination policy [5]. However, there are also studies concluding that BCG was not protective against COVID-19 [6,7]. WHO has stated that BCG vaccination for COVID-19 protection is not recommended due to the insufficient level of evidence yet [8]. Randomized controlled clinical studies are ongoing on this subject.

This study was conducted to investigate the effect of BCG vaccination in hospitalized patients with COVID-19 on the severity and mortality of the disease.

\section{Material and methods}

\section{Study design, setting, participants and ethics}

This study was a single center, retrospective observational study. Adult patients (> 18 years old) with COVID-19 hospitalized in Sultan 2. Abdulhamit Han Training and Research Hospital which is a tertiary center for COVID-19 in Istanbul, Turkey between April 15 and June 15, 2020 were included in the study. Ethics committee approval was obtained for the study. Patients with severe acute respiratory syndrome coronavirus 2 (SARS-CoV-2) polymerase chain reaction (PCR) positive in nasopharyngeal swap and those with SARS-CoV-2 PCR negative tests who were diagnosed with clinical, radiological, and laboratory findings were enrolled in the study. The data of the patients were analyzed retrospectively. The patients were divided into two groups as BCG scar positive and negative according to the presence of BCG scar. Oxygen desaturation was defined as the oxygen saturation $(\mathrm{SpO} 2)$ in room air measured by pulse oximetry was <93\%. Chest computed tomography scans were examined to evaluate the extent of lung involvement associated with COVID-19. According to radiological involvement scale, each of the 5 lobes was scored as; none (0\%) 0 point, minimal (1-25\%) 1 point, mild $(26-50 \%) 2$ points, moderate $(51-75 \%) 3$ points and severe $(76$ $100 \%) 4$ points $\square 9 \square$. Total radiological involvement score was obtained by summing the scores of 5 lobes ( $0-20$ point). Those with a radiology score of 0 point were in stage $0,1-5$ points were in stage $1,6-10$ points were in stage $2,11-15$ points were in stage 3 , and $16-20$ points were in stage 4 . BCG positive and negative groups were compared in terms of radiological involvement, presence of oxygen desaturation, need for intensive care unit (ICU) and intubation, and mortality.

\section{Statistical analysis}

The patient data collected in the study were analyzed with the IBM SPSS version 21.0 (Statistical Package for the Social Sciences, Chicago, IL, USA) package program. Frequency and percentage were used for discrete data and mean \pm standard deviation was given as descriptive values for continuous data. "Independent Sample t-test" was used to compare two groups between groups. Results were considered statistically significant when $\mathrm{p}$ value was less than 0.05 .

\section{Results}

A total of 233 hospitalized patients, 133 males and 100 females, were included in the study (Table 1).

Table 1. Demographic characteristics of the patients.

\begin{tabular}{llc} 
& & N $(\%)$ or mean \pm SD \\
\hline Gender & Male & $133(57.1)$ \\
Age (year) & Female & $100(42.9)$ \\
Hospital stay (day) & & $51 \pm 19.3$ \\
BCG scar & Negative & $9 \pm 7.0$ \\
& Positive & $52(22.3)$ \\
Radiological stage & 0 & $181(77.7)$ \\
& 1 & $28(12.0)$ \\
& 2 & $48(20.6)$ \\
Need for ICU & 3 & $94(40.3)$ \\
& 4 & $52(22.3)$ \\
Oxygen & No & $11(4.7)$ \\
desaturation & Yes & $170(73.0)$ \\
PCR & No & $63(27.0)$ \\
& Yes & $128(54.9)$ \\
Need for & Negative & $105(45.1)$ \\
intubation & Positive & $23(9.9)$ \\
Mortality & No & $210(90.1)$ \\
& Yes & $206(88.4)$ \\
& Survivor & $27(11.6)$ \\
& Non-survivor & $212(91.0)$ \\
SD: Standard & $21(9.0)$ \\
\hline
\end{tabular}

SD: Standard deviation, BCG: Bacillus Calmette Guerin, ICU: Intensive care unit, PCR: Polymerase chain reaction.

The mean age of the patients was $51 \pm 19.3$ years. The average length of stay in the hospital was $9 \pm 7.0$ days. Sixtythree of the patients have been treated in ICU and 105 patients had oxygen desaturation. Twenty-seven patients were intubated and needed mechanical ventilator support, and 21 patients died. BCG scar was positive in 181 and negative in 52 of the patients. There was no statistically significant difference between the BCG scar positive and negative patient groups in terms of gender and PCR test results (Table 2, $\mathrm{p}=0.341$ and $\mathrm{p}=0.305$ ). The mean age of BCG scar positive patients was $47 \pm 17.6$ years and the mean age of BCG scar negative patients was $64 \pm 19.2$ years, and the difference between the two groups was statistically significant $(\mathrm{p}<0.0001)$. When $\mathrm{BCG}$ scar positive and negative patients were compared in terms of length of hospitalization, it was found that BCG scar negative patients required statistically significantly more inpatient treatment $(12 \pm 6.7$ and $8 \pm 6.9$ days, $\mathrm{p}=0.001)$. The radiological involvement due to COVID-19 was 
more severe in BCG scar negative patients $(\mathrm{p}=0.016)$. Forty-one $(22.7 \%)$

Table 2. The comparison between patients with and without BCG vaccine.

\begin{tabular}{|c|c|c|c|}
\hline Variable & $\begin{array}{c}\text { BCG scar } \\
\text { Negative } \\
(\mathrm{N}: 52) \\
\mathrm{N}(\%) \text { or } \\
\text { mean } \pm \mathrm{SD} \\
\end{array}$ & $\begin{array}{c}\text { BCG scar } \\
\text { Positive } \\
(\mathrm{N}: 181) \\
\mathrm{N}(\%) \text { or } \\
\text { mean } \pm \mathrm{SD}\end{array}$ & $\mathrm{p}$ \\
\hline \multicolumn{4}{|l|}{ Gender } \\
\hline Male & $33(63.5)$ & $100(55.2)$ & 0.341 \\
\hline Female & $19(36.5)$ & $81(44.8)$ & 0.317 \\
\hline Age (year) & $64 \pm 19.2$ & $47 \pm 17.6$ & $<0.001$ \\
\hline $\begin{array}{l}\text { Hospital stay } \\
\text { (day) }\end{array}$ & $12 \pm 6.7$ & $8 \pm 6.9$ & 0.001 \\
\hline \multicolumn{4}{|l|}{ Radiological Stage } \\
\hline 0 & $2(3.8)$ & $26(14.4)$ & \multirow{5}{*}{0.016} \\
\hline 1 & $8(15.4)$ & $40(22.1)$ & \\
\hline 2 & $19(36.5)$ & $75(41.4)$ & \\
\hline 3 & $19(36.5)$ & $33(18.2)$ & \\
\hline 4 & $4(7.7)$ & $7(3.9)$ & \\
\hline Treated in ICU & $22(42.3)$ & $41(22.7)$ & 0.007 \\
\hline $\begin{array}{l}\text { Patients with } \\
\text { oxygen } \\
\text { desaturation }\end{array}$ & $31(59.6)$ & $74(40.9)$ & 0.018 \\
\hline PCR positive & $45(86.5)$ & $165(91.2)$ & 0.305 \\
\hline Intubated patients & $11(21.2)$ & $16(8.8)$ & 0.024 \\
\hline \multicolumn{4}{|l|}{ Mortality } \\
\hline Survivor & $43(82.7)$ & $169(93.4)$ & \\
\hline Non-survivor & $9(17.3)$ & $12(6.6)$ & 0.027 \\
\hline
\end{tabular}

BCG: Bacillus Calmette Guerin, SD: Standard deviation, ICU: Intensive care unit, PCR: Polymerase chain reaction.

patients in the BCG scar positive group and twenty-two (42.3\%) patients in the BCG scar negative group were treated in the ICU, and the difference in need for intensive care between the two groups was statistically significant $(p=0.007)$. More patients in the BCG scar negative group than the BCG scar positive group had oxygen desaturation $(59.6 \%$ vs. $40.9 \%, p=0.018)$. The number of intubated patients was $11(21.2 \%)$ in the BCG scar negative group and $16(8.8 \%)$ in the BCG scar positive group, and the difference was statistically significant $(\mathrm{p}=0.024)$. Nine $(17.3 \%)$ patients in the BCG scar negative group and $12(6.6 \%)$ patients in the BCG scar positive group died, and the difference was statistically significant $(\mathrm{p}=0.027)$

\section{Discussion}

In this study, patients who were hospitalized with COVID-19 were divided into two groups according to BCG vaccine status, and the effect of BCG on the length of hospital stay, the severity and the mortality of the disease was investigated. Patients in BCG scar negative group had longer length of hospital stay, more severe radiological involvement and oxygen desaturation. The need for ICU and intubation and mortality were also higher for non-vaccinated patients.

BCG vaccine has been shown to be protective against novel viruses by affecting the maturation and production of native $\mathrm{T}$ cells that cause accelerated and long-acting innate immune responses [10]. There is a negative correlation between reported COVID-19 cases and BCG vaccination status [11]. Miller et al. investigated the relationship between COVID-19 mortality and BCG vaccination programme in different countries. COVID-19 mortality was higher in countries such as Italy, the Netherlands and the USA where no national BCG vaccination program was implemented, than in countries with universal BCG vaccination policy, and having a policy of universal BCG vaccination correlated with a reduction in mortality associated with COVID-19 [12]. COVID-19 mortality was 5.8 times lower in countries where BCG vaccine is currently applied than in countries not applied (95\% CI, 1.8-19.0) [13]. Escobar et al. compared countries for deaths related to COVID19 by dividing them into 3 different groups (no BCG vaccination, discontinued and currently applying) according to BCG vaccination status. It was determined that for every $10 \%$ increase in BCG index, there was a $10.4 \%$ decrease in deaths [14]. In studies investigating the relationship between BCG and COVID-19, its effect on the spread of the disease as well as its effect on mortality was investigated.

The mandatory BCG vaccination policy, after controlling for other confounding factors, had a significant impact on the rate of increase in both the number of COVID-19 cases and deaths, and a significant advantage of the universal BCG policy in reducing the spread of COVID-19 [15]. A study conducted in Turkey, compared COVID-19 cases and deaths related with COVID-19 in different countries according to the BCG vaccination status and countries with national BCG vaccination programme had lower case numbers and mortality rates ( $\mathrm{p}<0.0001$ and $\mathrm{p}<0.0058$ ) [16]. A study from Israel showed a strong negative association between the ages of BCG administration and the spread and severity of COVID-19. This relationship was most prominent especially in younger $(<25$ years) population, and especially in recent vaccination [17]. According to a cohort study, COVID-19 patients with BCG vaccine needed less hospitalization during the course of the disease, and it has been suggested that BCG vaccination can prevent more severe COVID-19 [18]. The relationship between BCG vaccination and COVID-19 spread, severity and mortality has been investigated with mathematical modeling, and it has been observed that the rate of COVID-19 spread was lower, the hospital stay was shorter and the recovery rate was higher in those with BCG vaccination. The incidence of COVID-19, disease severity, and mortality were lower in countries where BCG has been used for a long time [19]. In this study, similar results to those in previous studies were obtained. In COVID-19 patients with BCG vaccination, length of hospital stay was shorter, disease severity was lower, oxygen desaturation, need for ICU and intubation, and mortality was lower.

There are also studies reporting that BCG is not protective against COVID-19. A study conducted with regression discontinuity method in Switzerland, which has stopped BCG vaccination in newborns since 1975, reported that BCG vaccination at birth did not have a protective effect against COVID-19 [20]. In another study, there was no relationship between universal BCG vaccination and COVID-19 mortality and the difficulties of obtaining reliable epidemiological results based on available data on the COVID-19 pandemic all over the world have been revealed [21]. There was no difference between the two groups $(p=0.9)$ in the study conducted in Israel comparing the rates of COVID-19 in BCG-vaccinated and nonvaccinated young people. BCG vaccine applied in childhood did not have a protective effect against COVID-19 in adulthood [22]. The relationship between BCG vaccination and COVID-19 pneumonia severity pneumonia was evaluated in a retrospective study in Turkey. 30 patients with BCG positive had mild disease and 61 patients had severe disease, and the difference was statistically significant $(p=0.026)$ in the study. Severe disease was more common in those who did not have BCG vaccines. 
However, in binominal logistic regression analysis, BCG vaccination was not found to be associated with the severity of COVID-19 pneumonia [6]. Wassenaar et al. also concluded that there was no available evidence that BCG vaccination has a beneficial effect on the number or fatality of COVID-19 reported cases [7].

Ecological studies have suggested that countries where BCG vaccination is mandatory have fewer COVID-19 cases, lower disease severity and mortality. However, the results of these studies should be evaluated carefully. Variables such as demographic features, genetic variabilities, differences in the treatment of COVID-19, the number of diagnostic tests, and the epidemiological period of the disease may affect the results of these studies. BRACE (Phase III, Australia), BCG-CORONA (Phase III, Netherlands) and BADAS (Phase IV, USA) randomized controlled studies on the protection of BCG against COVID-19 are continuing. The results of these studies can provide the necessary evidence in this regard [23].

The most important limitation of this study was that it was designed retrospectively. In addition, the patients included in the study were not randomized. The efficacy of the BCG vaccine varies on populations due to different BCG strains applied in different countries, genetic and geographic characteristics and exposure to non-mycobacterial infections.

In conclusion, the length of hospital stay was longer, radiological involvement was more severe, the need for ICU and intubation, oxygen desaturation and mortality were higher in BCG-unvaccinated patients with COVID-19.

\section{References}

1. Teo SS, Shingadia DV. Does BCG have a role in tuberculosis control and prevention in the United Kingdom? Arch Dis Child. 2006;91:529-31.

2. World Health Organization. BCG vaccine: WHO position paper, February 2018 - Recommendations. Vaccine. 2018;36:3408-10.

3. Yitbarek K, Abraham G, Girma T, Tilahun T, Woldie M. The effect of Bacillus Calmette-Guérin (BCG) vaccination in preventing severe infectious respiratory diseases other than TB: Implications for the COVID-19 pandemic. Vaccine. 2020;38:6374-80.

4. O'Neill LAJ, Netea MG. BCG-induced trained immunity: can it offer protection against COVID-19? Nat Rev Immunol. 2020;20:335-7.

5. Urashima M, Otani K, Hasegawa Y, Akutsu T. BCG Vaccination and Mortality of COVID-19 across 173 Countries: An Ecological Study. Int J Environ Res Public Health. 2020;17:5589.

6. Aksu K, Naziroğlu T, Özkan P. Factors determining COVID19 pneumonia severity in a country with routine BCG vaccination. Clin Exp Immunol. 2020:10.1111/cei.13507. DOI: $10.1111 /$ cei.13507.

7. Wassenaar TM, Buzard GS, Newman DJ. BCG vaccination early in life does not improve COVID-19 outcome of elderly populations, based on nationally reported data. Lett Appl Microbiol. 2020;71:498-505.

8. WHO. Bacille Calmette-Guérin (BCG) vaccination and COVID-19. WHO Scientific Brief; 2020. p.1-2.

9. Bernheim A, Mei X, Huang M, Yang Y, Fayad ZA, Zhang N, et al. Chest CT Findings in Coronavirus Disease-19 (COVID19): Relationship to Duration of Infection. Radiology. 2020;295:200463.

10. Hajjo R, Tropsha A. A Systems Biology Workflow for Drug and Vaccine Repurposing: Identifying Small-Molecule BCG Mimics to Reduce or Prevent COVID-19 Mortality. Pharm Res. 2020;37:212.

11. Mariita, R. M., Musila, J. M. A study on the relationship between Bacillus Calmette-Guérin (BCG) vaccination and
Covid-19 prevalence: Do other confounders warrant investigation? J Public Health Epidemiol. 2020;12:142-50.

12. Miller A, Reandelar MJ, Fasciglione K, Roumenova V, Li Y, Otazu GH. Correlation between universal BCG vaccination policy and reduced mortality for COVID-19. medRxiv 2020; preprint at https://doi.org/10.1101/2020.03.24.20042937.

13. Shet A, Ray D, Malavige N, Santosham M, Bar-Zeev N. Differential COVID-19-attributable mortality and BCG vaccine use in countries. medRxiv 2020; preprint at https://doi.org/10.1101/2020.04.01.20049478.

14. Escobar LE, Molina-cruz A, Barillas-mury C. BCG vaccine protection from severe coronavirus. Proc Natl Acad Sci U S A. 2020;117:17720-26.

15. Berg MK, Yu Q, Salvador CE, Melani I, Kitayama S. Mandated Bacillus Calmette-Guérin (BCG) vaccination predicts flattened curves for the spread of COVID-19. Sci Adv. 2020;6: eabc1463.

16. Gursel M, Gursel I. Is global BCG vaccination-induced trained immunity relevant to the progression of SARS-CoV-2 pandemic? Allergy. 2020;75:1815-9.

17. Klinger D, Blass I, Rappoport N, Linial M. Significantly Improved COVID-19 Outcomes in Countries with Higher BCG Vaccination Coverage: A Multivariable Analysis. Vaccines (Basel). 2020;8:E378.

18. Weng CH, Saal A, Butt WW, Bica N, Fisher JQ, Tao J, et al. Bacillus Calmette-Guérin vaccination and clinical characteristics and outcomes of COVID-19 in Rhode Island, United States: a cohort study. Epidemiol Infect. 2020;148:e140.

19. Shah NH, Suthar A, Satia MH, Shah Y, Shukla N, Shukla J, et al. Modelling the Impact of Nationwide BCG Vaccine Recommendations on COVID-19 Transmission, Severity, and Mortality. medRxiv 2020; preprint at https://doi.org/10.1101/2020.05.10.20097121.

20. de Chaisemartin C, de Chaisemartin L. BCG vaccination in infancy does not protect against COVID-19. Evidence from a natural experiment in Sweden. Clin Infect Dis. 2020: ciaa1223. DOI: 10.1093/cid/ciaa1223.

21. Szigeti R, Kellermayer D, Trakimas G, Kellermayer R. BCG epidemiology supports its protection against COVID-19? A word of caution. PLoS One. 2020;15:e0240203.

22. Hamiel U, Kozer E, Youngster I. SARS-CoV-2 Rates in BCG-Vaccinated and Unvaccinated Young Adults. JAMA. 2020;323:2340-1.

23. Charoenlap S, Piromsopa K, Charoenlap C. Potential role of Bacillus Calmette-Guérin (BCG) vaccination in COVID-19 pandemic mortality: Epidemiological and Immunological aspects. Asian Pac J Allergy Immunol. 2020;38:150-61. 